\title{
The Ethical Implications of Eco-Individualism on Sustainable Environment
}

\author{
Osebor Ikechukwu Monday ${ }^{1 *}$
}

\begin{abstract}
${ }^{1}$ Department of Arts and Humanities, Delta State Polytechnic Ogwashi-Uku PmB, NIGERIA
*Corresponding Author: Osebor.ikechukwu@mydspg.edu.ng
\end{abstract}

Citation: Monday, O. I. (2021). The Ethical Implications of Eco-Individualism on Sustainable Environment. European Journal of Sustainable Development Research, 5(3), em0167. https://doi.org/10.21601/ejosdr/11092

\section{ARTICLE INFO}

Received: 13 Apr. 2021

Accepted: 16 Jun. 2021

\begin{abstract}
Environmental ethics is a discipline, which specifies and analyzes how human being ought to behave. The significance of ethics is to provide guidelines for Subject-Object relationship (Ich-Es). Some may argue that "IchEs" is justified by environmental utilitarianism. The moral implications of environmental materialism/ecoindividualism include modification of the ecosystem, scarcity of resources/energy, drought, flooding and extinction of species. The question is how eco-individualism would or environmental self be resolved if not eliminated? Applying the method of philosophical analysis, this research explores the ethical implications of ecoindividualism. The objective of the research is to demonstrate how sustainable environmental education (SEE) could help to ameliorate the impacts of eco-individualism. Although sustainable environmental education is challenged by lack professional teaches and funds for its implementation but it reawakens environmental consciousness for the common good of humanity.
\end{abstract}

Keywords: ethics, sustainable environmental education, global warming, I-IT-relationship

\section{INTRODUCTION}

The environment provides various ecosystem services to humanity. The ecosystem services include climate regulation, nutrient cycling, food production, and leisure opportunities to human being (Kana, 2021). The relationship between human beings and non-sentient environment is anthropocentric burden has led to the ecological crisis.

Eco-individualism is "burdened by anthropogenic pressure resulting in threats, such as coastal eutrophication, marine pollution, destruction of habitat, overfishing, and discarded plastics" (Kana, 2021). The adverse effect of eco- individualism is climate change and is being experienced worldwide (Abolarin et al., 2013). The ecological materialism is an environmental damage, which distress people. It is "found in nature or created artificially, which is in a state of disequilibrium with the environment" (Rosen, 2021). This article discusses the ethical implications of eco-individualism, with the objective of demonstrating how sustainable environmental education (SEE) would help to ameliorate the environmental impacts of eco-individualism for environmental sustainability. The article concludes that government policy could help the implementation of sustainable environmental education at all levels in Nigeria educational system. The paper recommends that the teaching and learning of sustainable environmental education would be a practical approach for the environmental conservation.

\section{MATERIAL AND METHOD}

This research adopts the method of philosophical analysis. Philosophical analysis is a method of approaching problems through analysis of the terms used (Omoregbe, 1999). To 'analyze environmental terms,' it means to separate or break down them into constituent components or elements, i.e., to determine the essential features or characteristics that define the phenomena or concepts in question. Beaney (2019) holds that philosophical analysis consists of the breaking down of concepts into their constituent parts in order to gain an indepth understanding about things. However, philosophical analysis as a method of research, may not give final answer to philosophical problems due to difficulties in the interpretation of simple and component terms. Nonetheless, philosophical analysis would be a practical approach that proffers solution to the moral implications of eco-individualism.

\section{Ethics and Eco-Individualism}

Ethics is the study of how people ought to make their decisions. It focuses on how people ought to behave based on their moral compass or values, and society's shared values, laws, and traditions (Monday, 2020a, 2020b). Ethics is a 
fundamental thought of acceptable or unacceptable actions, although ethics is not a legal responsibility to others but a moral choice to act responsibly and avoiding individualistic attitude on the environment.

\section{What is Eco-individualism?}

Eco-individualism is a form of social political ecology that revolves around environmental self or egoism. It occurs when human beings assume moral superiority over other members of the earth. It is a Subject- Object relationship in a habitat. Martin Buber was one among philosophers who theorized on the concept of "Subject- Object relationship" (Buber, 1958). Subject-Object (Ich-Es) is the anthropocentric relationship, which overstrains other members of the earth. "Ich-Es" is the opposite of "I-thou" (Buber, 1958). The core of ecoindividualism is separation of human being from others. Ecoindividualism failed to establish environmental mutualism and deontology among beings. Instead, it isolates self from other beings. The environmental isolation is racism. It objectifies the ecological self. Eco- individualism is paternalism; treating other beings as an object or a means to an end (Morgan et al., 2012).

Eco-individualism is the appraisal of environmental egoism. Egoism expresses self as superior to other members of the earth (Persson, 2005). Subject- Object relationship promotes moral luck, profiteering, over consumption and ecological egoism. It opposes environmental holism and the vital needs for environmental resources. Environmental profiteering biases on eco- communalism. In this sense, the environment is viewed from the lens of individual choice or actions (Basic, n.d).

Eco-individualism is environmental marketing. It is a negative perception of nature (the ethical position that moral agents ought to do whatever is in their self-interest in the exploration of the environment) (Basic, n.d.). The effect of environmental egoism undermines ecological citizenship or holism, which has led to global warming.

The earth is in peril due to separateness among beings. (Moorthy and Akwen, 2020). The subject-object relationships threaten humanity. It is the emission of toxic gases at a quantity that is hazardous to man and the environment. Anthropogenic $\mathrm{CO} 2$ (Carbon dioxide) emissions from combustion accumulated $\mathrm{CO} 2$ within the atmosphere, which has led to global climate change and loss of biodiversity. The emission of carbon dioxide include energy related from human activities - that is, energy from heat, light, power, refrigeration and transport related emissions, which threatens existence humanity (Abolarin et al., 2013). Eco-individualism is the increase in the use of fossil fuel, over consumption, deforestation, industrialization, landfills and over interference with the natural water or carbon cycles, led to increase in ecological crisis. More than $40 \%$ of carbon emission in developing countries is due to the residential and tertiary sector pollution, which renders the environment uninhabitable (Abolarin et al., 2013).

Eco-individualism is a human-centred philosophy opposed eco-communalism (Monday, 2020a, 2020b). It is an act, which affirms the superiority of man in the hierarchy of being. Environmental atomism negates de-growth.
De-growth is a philosophy, which advocates reduction in human consumption. Over consumption is the act of treating other beings as a means to an end.

"De-growth" is an economic philosophy that began around the 1970s. The idea of increase consumption over the last few decades is destroying the biodiversity. Growth in population and increase in consumptions have taken place in poorer countries like Nigeria but contributed relatively to climate change. Environmental education is needed to promoting degrowth, energy savings, cost savings and environmental sustainability (Abolarin et al., 2014).

Eco-individualism is paternalism. It is the unscrupulous deployment of chemicals or pesticides to the environment. It weigh-down the flourishing earth, which creates chaos to the surroundings and the life of species that resides on earth (Carson, 1962: 2; Moorthy and Akwen, 2020).

The moral question is, how can human being seek to farm or fumigate by polluting the whole environment. Carson didn't oppose the use of chemicals but she argued that an acceptable method of handling chemicals is adapted to avoiding climate change (Carson, 1962: 2). The disruption of climate has caused the death of millions of people worldwide. World Health Organization reports that in (2012) over 8 million people died - one in nine of total global deaths - due to eco-individualism.

The moral questions; how would eco-individualism ameliorate if not eradicated? Should we protect the environment for posterity's sake? What kind of education needed to protect the environment? There are many approaches to avoiding the eco-individualism; environmental laws, deep ecological principle, eco-justice, Ukama, Ubuntu but sustainable environmental education is more practical approach to re-evaluate and re-orientate human beings to adopt positive environmental relativism. Sustainable environmental education teaches people how they ought to make their decisions for environmental sustainability. It guides on how people ought to behave based on their moral compass or values, and society's shared values, laws, and traditions (Monday, 2020a, 2020b). Sustainable environmental education teaches fundamental thought of acceptable or unacceptable actions.

\section{Sustainable Environmental Education}

Sustainable Environmental Education dated back to the works of Rousseau on nature, wholeness, and education. Rousseau maintains that sustainable environmental education is rooted in "man's natural state". The moral question what's man's natural state? The concept of "Natural state" means "simple framing community or state without evils, corruption and social classes. Natural man means that man is governed and directed by-laws of his nature instead of those of social institutions" (Jamwal, 2017).

Decades later, Jean Louis Rodolphe Agassiz (n-d) a Swissborn naturalist, re-echoed Rousseau's sustainable environmental education to inspire students about how to "Study nature not books." Sustainable environmental education is a holistic lifelong learning of de-growth, human responsibility to nature and effective actions for environmental sustainability (Galtseva et al., 2020). It is an eco-criticism, which teaches how to relate with the 
environment. Sustainable Environmental Education is an ecopedagogy, which provides focus for sustainable development. It is an ecological cosmopolitanism, ecological citizenship and environmental socialization. Sustainable environmental education helps human being to establish a symbiotic relationship with others (Galtseva et al., 2020; Sarbu et al., 2020). The objective of Sustainable environmental education is to producing citizens that are receptive to environmental. Galtseva et al. (2020) maintain that Sustainable environmental education is necessary for social-intercultural values. The preservationist education is a value-based education, which teaches the inculcation of environmental principles such as eco- kitchen and sustainable three R (Moorthy and Akwen, 2020). It is a participatory education that motivate and empower learners to adopt positive behaviour for the common good of humanity (Sustainable Edu, n.d).

Sustainable environmental education is the moral appraisal of eco-communalism and environmental symbiosis (Moorthy and Akwen, 2020). It teaches peace, justice and the transmission of values or knowledge about the environment. Galtseva et al. (2020) maintains that "Education for sustainable development is important for the formation of values and knowledge about a society that is in a state of balanced harmony with nature and provides balance between human's needs and its cooperation with the environment".

Sustainable environmental education is fundamental for the survival and wellbeing of humans and non-sentient beings (Daly and Zannetti, 2007; Ikeke, 2020). Sustainable environmental education frowns at overloading the environment with carbon, which poses threat to the continued existence of humanity. Lindsey (2018) argues, the global average atmospheric CO2 in the year 2017, is about 406.0 parts per million (ppm) with a variety of uncertainty of plus or minus $0.1 \mathrm{ppm}$. CO2 levels today are above at any point in the past 700,000 years, which is an unprecedented rise, in both size and speed of atmospheric $\mathrm{CO} 2$. The Inappropriate energy consumption is one among the causes of the unprecedented rise, in both size and speed of atmospheric $\mathrm{CO} 2$. We call for an improved method of energy consumption among individual and organizations.

SEE is an environmental advocacy, critical thinking, and problem-solving and decision-making skills for environmental justice. It teaches the individual about how to develop cognitive eco-socialization and to construct a responsible environmental relationship. Although we may have plundered and polluted our planet but environmental education is an important tool to reduce, reuse and recycle human damage to the environment (Arnold-Baker, 2011: 12-13). Moorthy and Akwen (2020) argues environmental education is the development of human personality, which exposes the human body, mind, and spirit. It arouses environmental sympathy, fellowship, deep feelings and environmental holism.

The objective of sustainable environmental education is a concise, declarative statement of "arête" in order to construct environmental altruism (Maheswari, 2013). The curriculum of sustainable environmental education would help for attitudinal change and environmental collaborations (Noel Gough et al., 2010). However, the domestication of sustainable environmental education as a single discipline is lacking in many institutions and communities in Nigeria. We suggest that policy-makers ensure the domestication of sustainable environmental education for the common good of humanity.

Sustainable environmental education is challenged by the non-availability of the latest research techniques, which could address the environmental crisis. We maintain that government at all levels should ensure adequate and prudent management of resources to discourage eco-individualism.

Across the federation of Nigeria exist, inadequate environmental teachers. This remains a challenge to the implementation of sustainable environmental education. Reexamination and training of environmental professionals are important. In addition, the efforts of the Nigerian government to conserve the environment remain futile due to inadequate funding (Challenges, n.d.). The constraints of heavy workload, poor teaching aids, and unavailability of manuals/handbooks affects sustainable environmental education (Norshariani Abd Rahman et al., 2018). We recommend frequent training and retraining of educators and the provision of teaching aids for the common good of humanity.

\section{CONCLUSION}

Despite the challenges of sustainable environmental education, we maintain that it relational learning and environmental pedagogy to improving the quality of the environment. The paper recommends a paradigm shift from eco-individualism to environmental holism through the teaching, learning and implementations of sustainable environmental education at all levels in Nigerian educational system. This paradigm shift would enable human being to reconsider the intrinsic value of all life forms; avoiding ecological materialism for the common good of humanity.

Funding: No external funding is received for this article.

Declaration of interest: Author declares no competing interests. Ethics approval and consent to participate: Not applicable.

Availability of data and materials: All data generated or analyzed during this study are available for sharing when appropriate request is directed to the author.

\section{REFERENCES}

Abd Rahman, N., Halim, L., Ahmad, A. R. and Soh, T. M. T. (2018). Challenges of environmental education: Inculcating behavioral changes among indigenous students. Creative Education, 9(1), 43-55. https://doi.org/10.4236/ce.2018.91004

Abolarin, S. M., Gbadegesin, A. O., Shitta, M. B., Yussuff, A., Eguma, C. A., Ehwerhemuepha, L. and Adegbenro, O. (2013). A collective approach to reducing carbon dioxide emission: A case study of four university of Lagos Halls of residence. Energy and Buildings, 61, 318-322. https://doi.org/10.1016/j.enbuild.2013.02.041 
Abolarin, S. M., Shitta, M. B., Nna, C. D., Eguma, C. A., Kedo, A. O., Yussuff, A., Babatunde, O. A., Onafeso, B. O. and Adegbenro, O. (2014). An approach to energy management: A case study of a medium scale printing press in Lagos, Nigeria. International Journal of Energy and Power Engineering, 3(1), 7-14. https://doi.org/10.11648/ j.ijepe.20140301.12

Agassiz, L. (n.d.). Study nature not books. Available at: https://ucmp.berkeley.edu/history/agassiz.html

Arnold-Baker, J. (2011). A lifetime of activism. Resurgence, (264). Available at: https://www.resurgence.org/magazine/ article3290-a-lifetime-of-activism.html

Basic Philosophy. Branch/ Doctrines Ethics Individualism. Available at: https://www.philosophybasics.com/ branch_individualism.html

Beaney, M. (2003). “Analysis”. The Stanford Encyclopedia of Philosophy. Available at: https://plato.stanford.edu/entries /analysis/

Buber, M. (1958). I and thou (trans. by R. G. Smith). New York: Charles Scribners's Son.

Campbell, R. L. (2006). Altruism in Auguste Comte and Ayn Rand. The Journal of Ayn Rand Studies, 7(2), 357-369. Available at: https://philoma.org/wp-content/uploads/ docs/2012_First_semester/Campbell___Altruism_in_Rand_ and_Comte.pdf

Carson, R. (1994). Silent spring: With an introduction by Vice President Al Gore. Houghton Mifflin New York.

Daly, A. and Zannetti, P. (2007). An introduction to air pollution - Definitions, classifications, and history. In P. Zannetti, D. Al-Ajmi and S. Al-Rashied (Eds.), Ambient air pollution (Chapter 1). The Arab School for Science and Technology (ASST) and The EnviroComp Institute. Available at: https://www.nile-center.com/uploads/ RQZG7BCW4DGXNSZ.pdf

Galtseva, T., Svitich, S., Kutsiy, A., Savchenko, V. and Strukova, T. (2020). Education for sustainable development in the value system of teachers. European Journal of Sustainable Development, 9(4), 147-160. https://doi.org/ 10.14207/ejsd.2020.v9n4p147

Ikeke, M. O. (2020). Deep ecology philosophy and biodiversity conservation in Nigeria's Niger Delta. European Journal of Sustainable Development, 9(2), 80-88. https://doi.org/ 10.14207/ejsd.2020.v9n2p80

Jamwal, B. S. (2017). Rousseau and his educational philosophy. Scholarly Research Journal for Humanity Science \& English Language, 4(24), 6530-6537. https://doi.org/10.21922/ srjhsel.v4i24.10327

Kuroda, K. (2021). Improving perceptions of the marine environment by hands-on environmental education: The case of Hannan City, Osaka, Japan. European Journal of Sustainable Development Research, 5(2), em0156. https://doi.org/10.21601/ejosdr/10843
Lindsey, R. (2018). Climate Change: Atmospheric Carbon Dioxide. Climate Watch Magazine. Available at: https://www.climate.gov/news-features/understandingclimate/climate-change-atmospheric-carbon-dioxide

Maheswari, J. (2013). Research objectives. https://www.slidesha re.net/maheswarijaikumar/research-objectives-108090672

Monday, O. I. (2020a). Ethics of cognitive restructuring: A rehabilitation of rape victims and offenders. Voices in Bioethics, 6. https://doi.org/10.7916/Vib.V6i.7223

Monday, O. I. (2020b) The relevance of deep ecological principles in aquatic crisis: A philosophical analysis. Bangladesh Journal of Bioethics, 11(2), 35-41. https://doi.org/10.3329/bioethics.v11i2.50392

Moorthy, R. and Akwen, G. T. (2020). Environmental ethics through value-based education. Bangladesh Journal of Bioethics, 11(2), 1-9. https://doi.org/10.3329/ bioethics.v11i2.49257

Morgan, W. J. and Guilherme, A. (2012). I and Thou: The educational lessons of Martin Buber's dialogue with the conflicts of his times. Educational Philosophy and Theory, 44(9), 979-996. https://doi.org/10.1111/j.1469-5812.2010. 00681.x

Noel, G. and Annette, G. (2010). Environmental education encyclopedia of curriculum studies (Vol. 1). Sage Publications.

Omoregbe, J. (1999). Contemporary philosophy (pp. 111-112). Lagos: Joja Educational Research and Publishing Ltd.

Persson, I. (2005). Moral individualism: Autonomy and agreement. Oxford Scholarship Online. https://doi.org/ 10.1093/0199276900.003.0029

Rosen, M. A. (2021). Exergy analysis as a tool for addressing climate change. European Journal of Sustainable Development Research, 5(2), em0148. https://doi.org/ 10.21601/ejosdr/9346

Sarbu, R., Niculescu, A. M., Buzoianu, O. A. C. and Gombos, S. P. (2020). Economic-Ecological Analysis of Sustainable Development in Romania. European Journal of Sustainable Development, 9(4), 161-168. https://doi.org/10.14207/ ejsd.2020.v9n4p161

UNESCO (2014). What is Education for Sustainable Development? Available at: https://www.plymouth.ac.uk/ students-and-family/sustainability/sustainabilityeducation/esd

World Health Organization. (2014). 7 million premature deaths annually linked to air pollution. Available at: https://www.who.int/mediacentre/news/releases/2014/air -pollution/en/ 